\title{
A Comparative Study of EFL Teachers' and Intermediate High School Students' Perceptions of Written Corrective Feedback on Grammatical Errors
}

\author{
Mina Jodaie (Corresponding author) \\ Department of ELT, Faculty of Literature and Foreign Languages \\ Tabriz Branch, Islamic Azad University, Tabriz, Iran \\ E-mail: Jodaiemina@gmail.com \\ Farahman Farrokhi \\ English Department, Faculty of Persian Literature and Foreign Languages \\ The University of Tabriz, Iran \\ E-mail: ffarrokhi20@yahoo.co.uk \\ Masoud Zoghi \\ Department of English Language Teaching, Faculty of Humanities \\ Ahar Branch, Islamic Azad University, Ahar, Iran \\ E-mail: m-zoghi@iau-ahar.ac.ir
}

Received: May 9, 2011

doi:10.5539/elt.v4n4p36
Accepted: July 20, 2011

Published: December 1, 2011

URL: http://dx.doi.org/10.5539/elt.v4n4p36

\begin{abstract}
This study was an attempt to compare EFL teachers' and intermediate high school students' perceptions of written corrective feedback on grammatical errors and also to specify their reasons for choosing comprehensive or selective feedback and some feedback strategies over some others. To collect the required data, the student version of questionnaire developed for the purposes of this study was distributed to 100 intermediate high school students who were selected based on their scores on a proficiency test. The matching teacher version of the above-mentioned questionnaire was also distributed to $30 \mathrm{EFL}$ teachers in language institutes. Semi-structured interviews with 8 teachers and 10 students were also carried out to provide more in-depth and qualitative data. Results showed that there are some important differences as well as similarities between teachers' and students' perceptions of written corrective feedback on grammatical errors. In addition, some unexpected differences in EFL teachers' perceptions of written corrective feedback were found. Overall, the present study can have some insightful implications for the field of EFL writing instruction.
\end{abstract}

Keywords: Corrective feedback, Comprehensiveness of written corrective feedback, Grammatical accuracy, Grammatical errors, Perceptions, Types of written corrective feedback

\section{Introduction}

Providing corrective feedback on student writing is one of the writing teacher's most difficult tasks (Enginarlar, 1993). Since Truscott published his 1996 article "The case against grammar correction", there has been some controversy on the usefulness of written corrective feedback in L2 classes (Ferris, 1999, 2002, 2004; 2007; Truscott, $1996,1999,2004,2007)$. While it is necessary to investigate the effectiveness of corrective feedback on students' written errors, it is also important to look at teachers' and students' perceptions of corrective feedback. In the case of written corrective feedback, teachers are believed to have the responsibility for selecting the appropriate way of providing such feedback. However, if both teachers and students share common ideas about feedback strategies, corrective feedback will be more productive (Diab, 2006). Despite a growing body of research on corrective feedback in writing classes, little research has compared second language teachers' and students' perceptions of written corrective feedback (Amrhein \& Nassaji, 2010; Diab, 2006; Halimi, 2008). In addition, Hong (2003) and 
Lee (2008) pointed to the paucity of research that includes high school students' perceptions of written corrective feedback. For example, Lee (2008) asserted that, "almost all of the feedback studies on student perceptions and preferences have been conducted in college/university settings" (p.145). Therefore, to contribute to the research into teachers' and high school students' perceptions of corrective feedback, this study was intended to compare EFL teachers' and intermediate high school students' perceptions of written corrective feedback on grammatical errors and also to specify their reasons for choosing comprehensive or selective feedback and some types of feedback strategy over some others.

\section{A Review of the Related Studies}

Regarding teachers' and students' perceptions of written corrective feedback, studies (Amrhein \& Nassaji, 2010; Diab, 2006; Halimi, 2008; Schulz, 2001) have showed some mismatches. It seems that L2 writing teachers are not fully aware of students' needs and opinions about corrective feedback. For example, Schulz (1996) explored FL teachers' and students' views on grammar correction and reported some mismatches. Schulz $(1996,2001)$ asserted that if students' specific expectations about corrective feedback are not met, language learning could be disturbed. Similarly, Kern (1995) investigated teachers' and students' beliefs about language learning and found that they had different ideas about pronunciation, error correction, and the importance of learning grammar and vocabulary. Diab (2006) compared EFL teachers' and students' perceptions of error correction and content feedback. The analysis revealed various differences between teachers' and students' preferences for error correction as well as differences in beliefs among teachers themselves. Truscott (1999) argued that students' preferences for and beliefs about grammar correction cannot be major factors for writing teachers and advised them to follow a "correction-free approach" (p.116). However, teachers have been reluctant to accept Truscott's advice (Hyland \& Hyland, 2006). In addition, the negative effects of mismatches between teachers' and students' perceptions of written corrective feedback on learning and teaching have been mentioned by many researchers (e.g., Amrhein \& Nassaji, 2010; Diab, 2006; Halimi, 2008; Schulz, 1996, 2001). Therefore, to improve the effectiveness of corrective feedback in writing classes, it is necessary to continue to conduct studies that not only compare teachers' and students' perceptions of written corrective feedback on grammatical errors, but also specify teachers' and students' reasons behind their perceptions.

\section{Methodology}

This study adopted a survey design. Two methods of data collection were used to obtain data for this study: questionnaire and semi- structured interview.

\subsection{Participants}

Thirty teachers who were teaching English in four private language institutes located in the eastern Azarbaijan province of Iran participated in the study. They had between three and eight years of EFL teaching experience at different proficiency levels in language institutes. Their highest TEFL qualification ranges from B.A. to M.A. Due to the problems of availability of teachers, sampling was not random. Therefore, convenience sampling was used in the study. One hundred intermediate high school students (57 females and 43 males) who were selected based on their scores on a proficiency test also took part in this study. They were selected out of a population of 111 high school students who were studying English as a foreign language in a private language institute located in the same province of Iran. The selected students, who were junior or senior in high school, were studying "Interchange 2" (Richards et al., 2005) or "Interchange 3" (Richards et al., 2005) as the main course books. These books contain 16 units, four of which were to be covered in 20 sessions. The courses had a writing component, although the focus was on developing conversation skills. By the time they answered the survey questions, they had done about three or four writing tasks in that specific term.

\subsection{Instruments}

Three instruments were used during the research: a Preliminary English Test, questionnaires, and semi- structured interviews.

\subsubsection{A Preliminary English Test}

The proficiency test employed in the present study was adopted from Preliminary English Test (PET, 2004). It included questions in reading comprehension, writing expressions, and listening comprehension.

\subsubsection{Questionnaires}

In this study, there were two versions of questionnaire: teacher questionnaire (Appendix A) and student questionnaire. Both teacher and student versions of questionnaire were based on Halimi's survey of Indonesian teachers' and students' preferences for the surface-level error correction (2008). However, some modifications and revisions were done to make the instrument more comparable with the purposes of this study. In order to obtain parallel data, the 
questionnaire for the teachers and the one used for the students were the same, but the questions were different in the sense that they asked the teachers to state their perceptions. The questionnaires included both closed-ended questions and open-ended questions. The closed-ended questions in the in Likert or multiple-choice formats were used to collect teacher and student perception data on:

- Grammatical accuracy in students' writing

- Types of grammatical errors that a teacher should correct

- When a teacher should correct grammatical errors

- Comprehensiveness of written corrective feedback

- How a teacher should correct grammatical errors

- Students' attention given to teachers' grammar corrections

- $\quad$ Types of written corrective feedback

Moreover, two open-ended questions were used to specify both teachers' and students' reasons for choosing comprehensive or selective feedback and some types of feedback strategy over some others.

\subsubsection{Semi-structured interviews}

The interviews were carried out to obtain more in-depth and qualitative data. In terms of structure, the interview with teachers covered four main areas: (1) comprehensive versus selective feedback; (2) teachers' current feedback strategies; (3) teachers' perceptions of other feedback strategies and (4) aspects of writing the teachers focus on in students' compositions. The interview with students, similarly, included four parts: (1) comprehensive versus selective feedback; (2) students' preferred feedback strategies; (3) students' perceptions of other feedback strategies and (4) aspects of writing their teachers focus on in their compositions.

\subsection{Procedures}

To ensure the teachers' and students' understanding, both teacher and student versions of questionnaire were translated into Farsi, and a pilot study was conducted to examine whether any questions were problematic in the questionnaires. In the main study, the Farsi version of student questionnaire was distributed to the selected students at their classes in the language institute in December 2010. At the same time, 30 teachers were requested to respond to the matching teacher version of questionnaire at home. Then, one-by-one-semi-structured interviews with eight teachers were carried out during their break time at the room for the teachers while the ones with ten students were conducted at their classes in the language institute.

\section{Results}

\subsection{Quantitative data}

As stated above, the teachers' and students' perceptions of written corrective feedback on grammatical errors were compared through seven categories of analysis. For the closed-ended questions in the questionnaires, percentages were determined through the statistical package for social sciences (SPSS, version 16).The results are as follows:

\subsubsection{Grammatical accuracy in students' writing}

The participants were requested to indicate the extent to which they agree or disagree with grammatical accuracy in students' writing. According to Table 1, 100\% of the teachers and $98 \%$ of the students thought that there should be as few grammatical errors as possible in compositions, and this was important to them. Therefore, almost all teachers and students seem to agree with grammatical accuracy in students' writing.

\subsubsection{Types of grammatical errors that a teacher should correct}

The data presented in Table 2 reveal that most of the teachers and students agreed about the types of grammatical errors that should be corrected, and that correction of errors in word and verb categories is more important to them than that of other grammatical errors.

\subsubsection{When a teacher should correct grammatical errors}

Table 3 presents the teachers' and students' perceptions of when grammatical errors should be corrected. The results indicate that the teachers were divided in their opinions on when to correct grammatical errors. Although $20 \%$ of the teachers stated that they provided corrective feedback on the first draft, $30 \%$ provided it on the second draft, 33.3\% provided it on the final draft, and $16.7 \%$ provided it on every draft. Unlike the teachers, there is minimal variation in the students' opinions on when to correct grammatical errors. A majority of students ( $72 \%)$ expected their teachers 
to provide written corrective feedback on every draft.

\subsubsection{Comprehensiveness of written corrective feedback}

Table 4 presents the teachers' and students' perceptions of comprehensiveness of written corrective feedback. The results indicate that all teachers provided corrective feedback on grammatical errors in student writing, to a certain degree, by addressing either all grammatical errors (comprehensive feedback) or only a few significant grammatical errors (selective feedback). The results also show that most of the teachers $(56.7 \%)$ and students $(86 \%)$ favored comprehensive feedback. However, unlike the students, the teachers were fairly divided in their perceptions of comprehensiveness of corrective feedback. Although $56.7 \%$ of the teachers preferred comprehensive feedback, $43.3 \%$ favored selective feedback.

\subsubsection{How a teacher should correct grammatical errors}

Table 5 displays the teachers and students' perceptions of how grammatical errors should be corrected. The results indicate that direct feedback (i.e., underlining/circling and correcting errors) was preferred by a majority of teachers $(70 \%)$ and students $(80 \%)$ as the only best technique to correct grammatical errors. Moreover, $20 \%$ of the teachers favored a combination of direct feedback and indirect, uncoded feedback (i.e., underlining/circling errors without coding them) as the best technique. Two teachers (6.7\%) stated that they preferred to provide oral feedback in class on common errors to supplement written direct feedback. In addition, one teacher (3.3\%) favored only indirect, coded feedback (i.e., underlining/circling and coding errors). Interestingly, no single teacher and student chose indirect prompting of error location by marks (e.g., a cross) or correction codes. Moreover, $6 \%$ of the students favored only indirect, uncoded feedback, and $14 \%$ preferred only indirect, coded feedback.

\subsubsection{Students' attention given to teachers' grammar corrections}

Table 6 displays the teachers and students' perceptions of students' attention given to teachers' grammar corrections. The results in the teacher group analysis indicate that $13.3 \%$ of the teachers thought that students read all grammar corrections carefully while $30 \%$ of the teachers believed that students looked at some corrections more carefully than at others. Over half of the teachers $(56.7 \%)$ also thought that students mainly paid attention to direct grammar corrections. Interestingly, no single teacher felt that students mainly paid attention to corrections showing directly or indirectly where the errors are (i.e., direct and indirect prompting of grammatical error location). The results in the student group analysis indicate that $23 \%$ of the students maintained that they read all grammar corrections carefully. A majority of students $(60 \%)$ felt that they looked at some grammar corrections more carefully than at others, whereas $13 \%$ of them thought that they mainly paid attention to direct grammar corrections. A much smaller percent of the students (4\%) also believed that they mainly paid attention to corrections showing directly where the errors are (i.e., direct prompting of grammatical error location).

\subsubsection{Types of written corrective feedback}

Table 7 displays the teachers and students' perceptions of types of written corrective feedback. The results reveal that direct feedback (i.e., underlining/circling and correcting errors) and indirect, coded feedback (i.e., underlining/circling and coding errors) received positive evaluations from most of the teachers $(90 \%$ and $80 \%$ respectively) and students ( $91 \%$ and $77 \%$ respectively). In addition, the teachers were fairly divided in their evaluations of indirect, uncoded feedback strategy (i.e., underlining/circling errors without coding them). Although $50 \%$ of the teachers provided a positive evaluation, $36.7 \%$ provided a negative evaluation. Unlike the teachers, a majority of students $(75 \%)$ provided a negative evaluation of indirect, uncoded feedback strategy. Moreover, indirect prompting of error location by marks (e.g., a cross) and correction codes received a negative evaluation from most of the teachers ( $80 \%$ and $66.6 \%$ respectively) and students ( $85 \%$ and $81 \%$ respectively).

\subsection{Qualitative data}

Data emerging from the open-ended questions in questionnaires and interviews were analyzed qualitatively. Due to the space limitation, details of the teachers' and students' ideas are not reported here. The relevant parts, however, will be presented in the following section.

\section{Discussion}

As the results showed, with regard to the topic of grammar correction, there were some important similarities as well as differences between the teachers' and students' perceptions. Accordingly, the following discussion will proceed from these two aspects.

\subsection{Similar perceptions}

The first common shared perception found among almost all participants was the importance of grammatical accuracy in students' writing and written corrective feedback on grammatical errors. The overwhelming support for 
grammatical accuracy and written corrective feedback on grammatical errors among the participants is in line with Ferris' $(1999,2002,2004,2006)$ argument and supports the idea that the use of written corrective feedback should be continued. This finding also supports Baleghizadeh and Farshchi's (2009) results that showed that Iranian EFL teachers appreciated the value of grammar and its role in language teaching. As the results of interviews with 10 students show, all of them expressed that, their teachers mainly focused on surface-level issues in their compositions. Thus, this may be one of the plausible factors that has formed the students' attitudes to grammatical accuracy in their writing because teachers' feedback practices can influence student perceptions and expectations (Lee, 2008; Rahimi, 2010). The teachers and students also agreed about the types of grammatical errors that should be corrected, and that correction of errors in word and verb categories was more important to them than of other grammatical errors. Word category errors are "the common type of errors for the L2 learners, especially for the Persian speakers since unlike many European languages, there are very few common lexical items in Persian and English" (Rahimi, 2009, p. 234). In addition, according to Ferris and Roberts (2001), the word category errors are untreatable and, as a result, not amenable to corrective feedback. English verb tenses and aspects also appear to be difficult for the Iranian learners of English. Rahimi (2009) found that verb errors can be considered as untreatable, at least for the Iranian learners of English unlike what Ferris and Roberts (2001) claimed.

Most of the teachers and students were also in favor of the provision of corrective feedback on grammatical errors comprehensively (i.e., addressing all grammatical errors). However, many error correction advocates have advised teachers against comprehensive feedback (e.g., see Ferris, 2002, 2007; Lee 1997, 2003, 2008). The interview data and open-ended answers throw light on the reasons why the teachers and students preferred marking grammatical errors comprehensively. These teachers probably find it hard not to point out all grammatical errors for students because they think that comprehensive feedback helps students improve grammatical accuracy of writing. In addition, students' preferences and language institutes' requests for comprehensive feedback seem to be important in this case. Moreover, they find it difficult to prioritize some students' grammatical errors. The teachers also think that because students are assigned to write about the topics that are according to their proficiency level, all their errors should be corrected. A majority of students who were in favor of receiving comprehensive feedback probably see marking all grammatical errors as the teachers' responsibility and think that their linguistic knowledge will improve if all errors are marked in their compositions. It seems that these students see writing tasks as the opportunities for language structure practice. On the other hand, the reasons why some teachers favored selective feedback indicated that they find comprehensive feedback as a time-consuming task and see other aspects of writing more important than surface-level issues like grammatical errors. These teachers also consider comprehensive feedback discouraging and de-motivating for students and find it ineffective for helping students avoid making the same errors again. A smaller number of students who preferred selective feedback find it hard to attend to all errors and feel less confident when they get back their compositions full of errors marked.

Direct feedback (i.e., underlining/circling and correcting errors) was the most preferred approach between both groups of teachers and students. Based on the interview data and open-ended answers, these teachers think that direct feedback triggers visual memory and makes corrections clear to students. These teachers seem to prefer the use of this strategy because they may not have enough time to let students perform self-editing or evaluation. Therefore, it seems that much of teachers' written corrective feedback is given to single drafts, and students are not required to perform self-editing or evaluation. In other words, these teachers seem to favor a single-draft approach over a multiple-draft approach. These teachers are likely to embrace the product approach to writing. The multiple-draft approach often involves much more effort as well as time than the single-draft approach.

Similarly, the students who favored direct feedback think that direct feedback helps them avoid making the same errors again, and that it makes the corrections clear to them. Moreover, these students consider the process of working out the correct answers by themselves as time-consuming. However, the teachers' and students' common preferences for the use of direct feedback does not seem to be so effective. Because most of the teachers favor direct feedback as the only best technique to mark grammatical errors, treat different grammatical categories equally, and provide no opportunities for student- centered activities, students can become passive and more and more reliant on teachers (Amrhein \& Nassaji, 2010; Lee, 2008). In addition, previous studies (Frantzen, 1995; Ferris \& Roberts, 2001; Lee, 1997; Makino, 1993) have reported that learners have some ability to self-correct their own errors and can improve levels of accuracy in writing when they are provided with indirect feedback on their writing. Therefore, it is important for teachers not to locate all errors and provide correct alternatives. Without being asked to perform self-editing or evaluation, students are not provided with opportunities to develop responsibility for learning (Amrhein \& Nassaji, 2010; Lee, 2009). Except for indirect, uncoded feedback strategy, most of the teachers and students shared common perceptions of types of written corrective feedback. Although most of the teachers and students evaluated indirect, coded feedback positively, during the interviews or in their open-ended responses they 
referred to some possible problems of the use of correction codes. The important problems that the teachers stated are as follows:

Possible confusing nature of the use of correction codes for students

-Difficulty of categorizing some grammatical errors according to the correction codes

-Time-consuming process of categorizing errors according to the correction codes

The students' main problems about the teachers' use of correction codes relate to the following:

-Confusing nature of correction codes

-Difficulty of knowing what some correction codes refer to

The teachers also stated that indirect prompting of error location can confuse students, and that the intermediate students need to know clearly, where their errors are located. The result that no single teacher preferred or used indirect prompting of error location is similar to the findings in Lee (2003).

\subsection{Different perceptions}

The findings of the present study showed that the teachers were divided in their opinions on when corrective feedback on grammatical errors should be provided. It can be concluded that the teachers were not sure when it is best to provide corrective feedback on grammatical errors in student writing. This finding is in line with that of Halimi (2008).Unlike the teachers, there is minimal variation in the students' opinions on when to correct grammatical errors. A majority of students expected their teachers to correct grammatical errors on every draft. This finding confirms again the students' high preferences for receiving written corrective feedback on their grammatical errors. The result, in this respect, supports the studies that have investigated the EFL/ESL students' preferences for grammar correction (e.g., Radecki \& Swales, 1988; Leki, 1991; Satio, 1994; Ferris \& Robert, 2001). Although most of the teachers (56.7\%) stated that students mainly paid attention to direct grammar corrections, $61 \%$ of the students stated that they looked at some grammar corrections more carefully than at others. This is in line with the students' responses to the questions that elicit their perceptions of types of grammatical errors that should be corrected. That is, they valued correction of grammatical errors differently, and that correction of errors in word and verb categories was more important to them than of other grammatical errors. Finally, a majority of teachers and students had different perceptions of indirect, uncoded feedback (i.e., underlining/circling errors without coding them). Moreover, the teachers were again divided in their evaluations of indirect, uncoded feedback strategy. Such discrepancies in EFL teachers' perceptions of written corrective feedback have also been reported in other studies (e.g., see Amrhein \& Nassaji, 2010; Diab, 2006; Halimi, 2008; Schulz, 1996).

\section{Conclusion}

The comparative study on written corrective feedback as reported in this paper discovered some important differences as well as similarities between EFL teachers' and intermediate high school students' perceptions. The results can be summarized as follows:

Similarities:

1. The teachers and students had negative perceptions of grammatical errors and strongly valued grammatical accuracy and written corrective feedback on student writing.

2. The teachers and students agreed about the types of grammatical errors that should be corrected.

3. The teachers and students agreed about comprehensive feedback.

4. The teachers and students shared common perceptions of how a teacher should correct grammatical errors. They preferred direct feedback as the only best technique.

5. The teachers and students shared common positive evaluations of direct feedback and indirect, coded feedback and common negative evaluations of indirect prompting of error location.

Differences:

1. The teachers and students had different perceptions of when a teacher should correct grammatical errors.

2. The teachers and students had different perceptions of students' attention given to teachers' grammar corrections.

3. The teachers and students did not share common evaluations of indirect, uncoded feedback strategy.

This study also revealed that some common perceptions between teachers and students are not always effective. That is, a majority of teachers and students in this study were in agreement with the use of written direct feedback on all grammatical errors. Among its major findings, the study also revealed that teachers themselves were fairly 
divided in their perceptions of when a teacher should correct grammatical errors, comprehensiveness of written corrective feedback, and indirect, uncoded feedback. Such differences among the teachers can be harmful to EFL writing instruction. Overall, this study revealed that the policies of the language institutes where the study was conducted might require teachers to provide corrective feedback on all errors, although this way is not necessarily effective. Therefore, teacher empowerment within the language institute system seems to be necessary. As a closing comment, although teacher education and training programs intend to build up teachers' teaching skills and provide them with the necessary know-how to use their initiative, the realization of change in language pedagogy, as Lee (2011) also asserted, is mainly dependent on to what extent teachers are given autonomy to help enrich learning experiences in their own work contexts.

\section{References}

Amrhein, H. R., \& Nassaji, H. (2010). Written corrective feedback: What do students and teachers prefer and why? Canadian Journal of Applied Linguistics, 13, 95-127

Baleghizadeh, S., \& Farshchi, S. (2009). An exploration of teachers' beliefs about the role of grammar in Iranian high schools and private language institutes. Journal of English Language Teaching and Learning, 52, 17-52

Diab, R. L. (2006). Error correction and feedback in the EFL writing classroom: Comparing instructor and student preferences. English Teaching Forum, 44(3), 2-13

Enginarlar, H. (1993). Student response to teacher feedback in EFL writing. System, 21(2), 109-204

Ferris, D. R. (1999). The case for grammar correction in L2 writing classes. A response to Truscott (1996). Journal of second Language Writing, 8, 1-10

Ferris, D. R. (2002). Treatment of error in second language student writing. Ann Arbor: University of Michigan press.

Ferris, D. R. (2004). The grammar correction debate in L2 writing: Where are we, and where do we go from here? Journal of Second Language Writing, 13, 49-62

Ferris, D. R. (2006). Does error feedback help student writers? New evidence on the short and long-term effects of written error correction. In K. Hyland \& F. Hyland (Eds.), Feedback in second language writing: Contexts and issues. Cambridge: Cambridge University Press. pp. 81-104

Ferris, D. R. (2007). Preparing teachers to respond to student writing. Journal of Second Language Writing, 16, $165-193$

Ferris, D. R., \& Roberts, B. (2001). Error feedback in L2 writing classes: How explicit does it need to be? Journal of Second Language Writing, 10, 161-184

Frantzen, D. (1995). The effects of grammar supplementation on written accuracy in an intermediate Spanish content course. Modern Language Journal, 79, 329-344.

Halimi, S. S. (2008). Indonesian teachers' and students' preferences for error correction. Wacana, 10(1), 50-71

Hong, P. C. (2003). Investigating teachers' and secondary students' preferences towards direct or indirect feedback on students' writing: Which way is more helpful. [Online] Available: www2.ied.edu.hk/mentoring/wals08/download.asp?code=057\&ptype.

Hyland, K., \& Hyland, F. (2006). Feedback on second language students' writing. Language Teaching, 39, 83-101

Kern, R. G. (1995). Students' and teachers' beliefs about language learning. Foreign Language Annals, 28(1), 71-92. http://dx.doi.org/10.1111/j.1944-9720.1995.tb00770.x

Lee, I. (1997). ESL Learners' Performance in Error Correction in Writing. System, 25(4), 465-477. http://dx.doi.org/10.1016/S0346-251X(97)00045-6

Lee, I. (2003). How do Hong Kong English teachers correct errors in writing? Education Journal, 31 (1), 153-169

Lee, I. (2008). Student reactions to teacher feedback in two Hong Kong secondary classrooms. Journal of Second Language Writing, 17, 144-164. http://dx.doi.org/10.1016/j.jslw.2007.12.001

Lee, I. (2009).Ten mismatches between teachers' beliefs and written feedback practice. ELT Journal, 63(1), 13-22. http://dx.doi.org/10.1093/elt/ccn010

Lee, I. (2011). Feedback revolution: What gets in the way? ELT Journal, 65(1), 1-12. http://dx.doi.org/10.1093/elt/ccp028

Leki, I. (1991). The preferences of ESL students for error correction in college-level writing classes. Foreign 
Language Annals, 24(3), 203-218. http://dx.doi.org/10.1111/j.1944-9720.1991.tb00464.x

Makino, T. (1993). Learner self- correction in EFL written compositions. ELT Journal, 47(4), 337-341. http://dx.doi.org/10.1093/elt/47.4.337

Radecki, P. M., \& Swales, J. M. (1988). ESL student reaction to written comments on their written work. System, 16 (3), 355-365

Rahimi, M. (2009). The role of teacher's corrective feedback in improving Iranian EFL learners' writing accuracy over time: Is learner's mother tongue relevant? Springer, 22, 219-243

Rahimi, M. (2010). Iranian EFL students' perceptions and preferences for teachers' written feedback: Do students' ideas reflect teachers' practice? The Journal of Teaching Language Skills, 2(2), 75-98

Richards, J. C., Hull, J., \& Proctor, S. (2005). Interchange Student's Book 2. New York: Cambridge University Press.

Richards, J. C., Hull, J., \& Proctor, S. (2005). Interchange Student's Book 3. New York: Cambridge University Press.

Satio, H. (1994). Teachers' and students' preferences for feedback on second language acquisition: A case study of adult ESL learners. TESL Canada Journal, 11 (2), 46 - 68

Schulz, R. A. (1996). Focus on form in the foreign language classroom: Students' and teachers' views on error correction and the role of grammar. Foreign Language Annals, 29(3), 343-364. http://dx.doi.org/10.1111/j.1944-9720.1996.tb01247.x

Schulz, R. A. (2001). Cultural differences in student and teacher perceptions concerning the role of grammar instruction and corrective feedback: USA-Columbia. Modern Language Journal, 85(2), 244-258. http://dx.doi.org/10.1111/0026-7902.00107

Truscott, J. (1996). The case against grammar correction in L2 writing classes. Language Learning, 46(2), 103-110. http://dx.doi.org/10.1111/j.1467-1770.1996.tb01238.x

Truscott, J. (1999). The case for "The case for grammar correction in L2 writing classes": A response to Ferris. Journal of Second Language Writing, 8, 111-122. http://dx.doi.org/10.1016/S1060-3743(99)80124-6

Truscott, J. (2004). Evidence and conjecture on the effects of correction: A response to Chandler. Journal of Second Language Writing, 13, 337-343

Truscott, J. (2007). The effect of error correction on learners' ability to write accurately. Journal of Second Language Writing, 16, 255-272

Table 1. Perceptions of Grammatical Accuracy in Students' Writing

\begin{tabular}{|l|c|c|c|c|}
\hline \multirow{2}{*}{ Grammatical accuracy } & \multicolumn{2}{|c|}{ Teachers } & \multicolumn{2}{c|}{ Students } \\
\cline { 2 - 5 } & Frequency & Percent & Frequency & Percent \\
\hline Strongly agree/agree & 30 & $100 \%$ & 98 & $98 \%$ \\
\hline Neither agree nor disagree & 0 & $0 \%$ & 2 & $2 \%$ \\
\hline Strongly disagree/ disagree & 0 & $0 \%$ & 0 & $0 \%$ \\
\hline Total & 30 & $100 \%$ & 100 & $100 \%$ \\
\hline
\end{tabular}


Table 2. Perceptions of Types of Grammatical errors that a Teacher Should Correct

\begin{tabular}{|c|c|c|c|c|c|c|c|c|c|c|}
\hline \multicolumn{11}{|c|}{ Grammatical errors } \\
\hline & \multicolumn{2}{|c|}{ Verb errors } & \multicolumn{2}{|c|}{$\begin{array}{l}\text { Noun ending } \\
\text { errors }\end{array}$} & \multicolumn{2}{|c|}{ Article errors } & \multicolumn{2}{|c|}{ Wrong word } & \multicolumn{2}{|c|}{ Sentence errors } \\
\hline \multirow{3}{*}{ Responses } & $\mathrm{T}$ & $\mathrm{S}$ & $\mathrm{T}$ & $\mathrm{S}$ & $\mathrm{T}$ & $\mathrm{S}$ & $\mathrm{T}$ & $\mathrm{S}$ & $\mathrm{T}$ & $\mathrm{S}$ \\
\hline & $(\%)$ & $(\%)$ & $(\%)$ & $(\%)$ & $(\%)$ & $(\%)$ & $(\%)$ & $(\%)$ & $(\%)$ & $(\%)$ \\
\hline & $\mathrm{F}$ & $\mathrm{F}$ & $\mathrm{F}$ & $\mathrm{F}$ & $\mathrm{F}$ & $\mathrm{F}$ & $\mathrm{F}$ & $\mathrm{F}$ & $\mathrm{F}$ & $\mathrm{F}$ \\
\hline $\begin{array}{l}\text { Strongly } \\
\text { agree / } \\
\text { agree }\end{array}$ & $\begin{array}{l}90 \% \\
(27)\end{array}$ & $\begin{array}{l}94 \% \\
(94)\end{array}$ & $\begin{array}{l}76.7 \\
\% \\
(23)\end{array}$ & $\begin{array}{l}76 \% \\
(76)\end{array}$ & $\begin{array}{l}80 \% \\
(24)\end{array}$ & $\begin{array}{l}78 \% \\
(78)\end{array}$ & $\begin{array}{l}93.3 \\
\% \\
(28)\end{array}$ & $\begin{array}{l}95 \% \\
(95)\end{array}$ & $\begin{array}{l}83.3 \\
\% \\
(25)\end{array}$ & $\begin{array}{l}88 \% \\
(88)\end{array}$ \\
\hline $\begin{array}{l}\text { Neither } \\
\text { agree nor } \\
\text { disagree }\end{array}$ & $\begin{array}{l}10 \% \\
(3)\end{array}$ & $\begin{array}{l}6 \% \\
(6)\end{array}$ & $\begin{array}{l}23.3 \\
\% \\
(7)\end{array}$ & $\begin{array}{l}10 \% \\
(10)\end{array}$ & $\begin{array}{l}20 \% \\
(6)\end{array}$ & $\begin{array}{l}13 \% \\
(13)\end{array}$ & $\begin{array}{l}6.7 \% \\
(2)\end{array}$ & $\begin{array}{l}5 \% \\
(5)\end{array}$ & $\begin{array}{l}16.7 \\
\% \\
(5)\end{array}$ & $\begin{array}{l}10 \% \\
(10)\end{array}$ \\
\hline $\begin{array}{l}\text { Strongly } \\
\text { disagree/ } \\
\text { disagree }\end{array}$ & $\begin{array}{l}0 \% \\
(0)\end{array}$ & $\begin{array}{l}0 \% \\
(0)\end{array}$ & $\begin{array}{l}0 \% \\
(0)\end{array}$ & $\begin{array}{l}14 \% \\
(14)\end{array}$ & $\begin{array}{l}0 \% \\
(0)\end{array}$ & $\begin{array}{l}9 \% \\
(9)\end{array}$ & $\begin{array}{l}0 \% \\
(0)\end{array}$ & $\begin{array}{l}0 \% \\
(0)\end{array}$ & $\begin{array}{l}0 \% \\
(0)\end{array}$ & $\begin{array}{l}2 \% \\
(2)\end{array}$ \\
\hline Total & $\begin{array}{l}100 \\
\% \\
(30)\end{array}$ & $\begin{array}{l}100 \\
\% \\
(100)\end{array}$ & $\begin{array}{l}100 \% \\
(30)\end{array}$ & $\begin{array}{l}100 \% \\
(100)\end{array}$ & $\begin{array}{l}100 \% \\
(30)\end{array}$ & $\begin{array}{l}100 \\
\% \\
(100 \\
)\end{array}$ & $\begin{array}{l}100 \% \\
(30)\end{array}$ & $\begin{array}{l}100 \% \\
(100)\end{array}$ & $\begin{array}{l}100 \% \\
(30)\end{array}$ & $\begin{array}{l}100 \% \\
(100)\end{array}$ \\
\hline
\end{tabular}

Note: T: Teachers, S: Students, F: Frequency, \%: Percent

Table 3. Perceptions of When a Teacher Should Correct Grammatical Errors

\begin{tabular}{|l|c|c|c|c|}
\hline \multirow{2}{*}{ Drafts } & \multicolumn{2}{|c|}{ Teachers } & \multicolumn{2}{c|}{ Students } \\
\cline { 2 - 5 } & Frequency & Percent & Frequency & Percent \\
\hline On the first draft & 6 & $20 \%$ & 18 & $18 \%$ \\
\hline On the second draft & 9 & $30 \%$ & 7 & $7 \%$ \\
\hline On the final draft & 10 & $33.3 \%$ & 3 & $3 \%$ \\
\hline On every draft & 5 & $16.7 \%$ & 72 & $72 \%$ \\
\hline On other drafts & 0 & $0 \%$ & 0 & $0 \%$ \\
\hline Total & 30 & $100 \%$ & 100 & $100 \%$ \\
\hline
\end{tabular}

Table 4. Perceptions of Comprehensiveness of Written Corrective Feedback

\begin{tabular}{|l|c|c|c|c|}
\hline \multirow{2}{*}{ Comprehensiveness } & \multicolumn{2}{|c|}{ Teachers } & \multicolumn{2}{c|}{ Students } \\
\cline { 2 - 5 } & Frequency & percent & Frequency & percent \\
\hline Comprehensive feedback & 17 & $56.7 \%$ & 86 & $86 \%$ \\
\hline Selective feedback & 13 & $43.3 \%$ & 14 & $14 \%$ \\
\hline No grammar feedback & 0 & $0 \%$ & 0 & $0 \%$ \\
\hline Total & 30 & $100 \%$ & 100 & $100 \%$ \\
\hline
\end{tabular}


Table 5. Perceptions of How a Teacher Should Correct Grammatical Errors

\begin{tabular}{|l|c|c|c|c|}
\hline Feedback strategies & \multicolumn{2}{|c|}{ Teachers } & \multicolumn{2}{c|}{ Students } \\
\cline { 2 - 5 } & Frequency & Percent & Frequency & Percent \\
\hline Direct feedback & 21 & $70 \%$ & 80 & $80 \%$ \\
\hline Indirect,uncoded feedback & 0 & $0 \%$ & 6 & $6 \%$ \\
\hline Indirect, coded feedback & 1 & $3.3 \%$ & 14 & $14 \%$ \\
\hline $\begin{array}{l}\text { Indirect prompting of error } \\
\text { location by marks (e.g., a } \\
\text { cross) }\end{array}$ & 0 & $0 \%$ & 0 & $0 \%$ \\
\hline $\begin{array}{l}\text { Indirect prompting of error } \\
\text { location by correction codes }\end{array}$ & 0 & $0 \%$ & 0 & $0 \%$ \\
\hline $\begin{array}{l}\text { Combined (a direct-indirect, } \\
\text { uncoded feedback }\end{array}$ & 6 & $20 \%$ & 0 & $0 \%$ \\
\hline $\begin{array}{l}\text { Other (direct feedback + } \\
\text { oral feedback in class on } \\
\text { common errors ) }\end{array}$ & 2 & $6.7 \%$ & 0 & $0 \%$ \\
\hline \begin{tabular}{l} 
Total \\
\hline
\end{tabular} & 30 & $100 \%$ & 100 & $100 \%$ \\
\hline
\end{tabular}

Table 6. Perceptions of Student Attention Given to Teachers' Grammar Corrections

\begin{tabular}{|c|c|c|c|c|}
\hline \multirow{2}{*}{$\begin{array}{c}\text { Teachers' grammar } \\
\text { corrections }\end{array}$} & \multicolumn{2}{|c|}{ Teachers } & \multicolumn{2}{c|}{ Students } \\
\cline { 2 - 5 } All grammar corrections & 4 & $13.3 \%$ & 23 & $23 \%$ \\
\hline $\begin{array}{c}\text { Some grammar corrections } \\
\text { Firect grammar } \\
\text { corrections }\end{array}$ & 17 & $30 \%$ & 60 & $60 \%$ \\
\hline $\begin{array}{c}\text { Direct prompting of } \\
\text { grammatical error location }\end{array}$ & 0 & $0 \%$ & 13 & $13 \%$ \\
\hline $\begin{array}{c}\text { Indirect prompting of } \\
\text { grammatical error location }\end{array}$ & 0 & $0 \%$ & 4 & $4 \%$ \\
\hline Other & 0 & $0 \%$ & 0 & $0 \%$ \\
\hline Total & 30 & $100 \%$ & 100 & $100 \%$ \\
\hline
\end{tabular}


Table 7. Perceptions of Types of Written Corrective Feedback

\begin{tabular}{|c|c|c|c|c|c|c|c|c|c|c|}
\hline \multicolumn{11}{|c|}{ Types of written corrective feedback } \\
\hline & \multicolumn{2}{|c|}{$\begin{array}{l}\text { Direct } \\
\text { feedback }\end{array}$} & \multicolumn{2}{|c|}{$\begin{array}{l}\text { Indirect, } \\
\text { uncoded } \\
\text { feedback }\end{array}$} & \multicolumn{2}{|c|}{$\begin{array}{l}\text { Indirect, coded } \\
\text { feedback }\end{array}$} & \multicolumn{2}{|c|}{$\begin{array}{l}\text { Indirect } \\
\text { prompting of } \\
\text { error location } \\
\text { by marks (e.g., } \\
\text { a cross) }\end{array}$} & \multicolumn{2}{|c|}{$\begin{array}{l}\text { Indirect } \\
\text { prompting of } \\
\text { error location } \\
\text { by correction } \\
\text { codes }\end{array}$} \\
\hline \multirow{3}{*}{ Responses } & $\mathrm{T}$ & $\mathrm{S}$ & $\mathrm{T}$ & $\mathrm{S}$ & $\mathrm{T}$ & S & $\mathrm{T}$ & $\mathrm{S}$ & $\mathrm{T}$ & $\mathrm{S}$ \\
\hline & $(\%)$ & $(\%)$ & $(\%)$ & $(\%)$ & $(\%)$ & $(\%)$ & $(\%)$ & $(\%)$ & $(\%)$ & $(\%)$ \\
\hline & $\mathrm{F}$ & $\mathrm{F}$ & $\mathrm{F}$ & $\mathrm{F}$ & $\mathrm{F}$ & $\mathrm{F}$ & $\mathrm{F}$ & $\mathrm{F}$ & $\mathrm{F}$ & $\mathrm{F}$ \\
\hline \multirow{2}{*}{$\begin{array}{l}\text { Very } \\
\text { good/ } \\
\text { good }\end{array}$} & $90 \%$ & $91 \%$ & $50 \%$ & $14 \%$ & $80 \%$ & $77 \%$ & $13.3 \%$ & $5 \%$ & $16.7 \%$ & $14 \%$ \\
\hline & (27) & $(91)$ & (15) & (14) & (24) & (77) & (4) & (5) & (5) & (14) \\
\hline \multirow{2}{*}{$\begin{array}{l}\text { Neither } \\
\text { good nor } \\
\text { bad }\end{array}$} & $10 \%$ & $2 \%$ & $13.3 \%$ & $11 \%$ & $13.3 \%$ & $11 \%$ & $6.7 \%$ & $10 \%$ & $16.7 \%$ & $5 \%$ \\
\hline & (3) & (2) & (4) & (11) & (4) & (11) & (2) & $(10)$ & (5) & (5) \\
\hline \multirow{2}{*}{$\begin{array}{l}\text { Very } \\
\text { bad/bad }\end{array}$} & $0 \%$ & $7 \%$ & $36.7 \%$ & $75 \%$ & $6.7 \%$ & $12 \%$ & $80 \%$ & $85 \%$ & $66.6 \%$ & $81 \%$ \\
\hline & (0) & (7) & (11) & (75) & (2) & (12) & (24) & (85) & (20) & (81) \\
\hline \multirow{2}{*}{ Total } & $100 \%$ & $100 \%$ & $100 \%$ & $100 \%$ & $100 \%$ & $100 \%$ & $100 \%$ & $100 \%$ & $100 \%$ & $100 \%$ \\
\hline & (30) & (100) & (30) & (100) & (30) & (100) & (30) & (100) & $(30)$ & (100) \\
\hline
\end{tabular}

Note: T: Teachers, S: Students, F: Frequency, \%: Percent

\section{Appendix A: Teacher Questionnaire}

What are your perceptions of written corrective feedback on grammatical errors?

I am conducting a research on corrective feedback in the EFL writing classroom. I hope that you will be cooperative and supportive to help me fulfill my research.

Educational degree:

Years of experience as a Foreign Language Teacher:

\section{Note: Remember that the following questions are intended for the intermediate level students.}

Part I. Directions: Please show your opinion about each statement by circling one of the numbers from 1 (strongly agree) to 5 (strongly disagree). There are no right or wrong answers. I am simply interested in your opinions.

\begin{tabular}{|c|c|c|c|c|c|}
\hline Questions & $\begin{array}{l}\text { Strongly } \\
\text { agree }\end{array}$ & Agree & $\begin{array}{l}\text { Neither } \\
\text { agree nor } \\
\text { disagree }\end{array}$ & Disagree & $\begin{array}{l}\text { Strongly } \\
\text { disagree }\end{array}$ \\
\hline $\begin{array}{l}\text { 1. It is important to me that students have } \\
\text { as few grammatical errors as possible in } \\
\text { their compositions. }\end{array}$ & 1 & 2 & 3 & 4 & 5 \\
\hline \multicolumn{6}{|l|}{ 2. It is important to me to point out: } \\
\hline $\begin{array}{l}\text { a. verb errors in the students' } \\
\text { compositions. }\end{array}$ & 1 & 2 & 3 & 4 & 5 \\
\hline $\begin{array}{l}\text { b. noun ending errors in the students' } \\
\text { compositions. }\end{array}$ & 1 & 2 & 3 & 4 & 5 \\
\hline $\begin{array}{l}\text { c. article errors in the students' } \\
\text { compositions. }\end{array}$ & 1 & 2 & 3 & 4 & 5 \\
\hline $\begin{array}{l}\text { d. wrong word in the students' } \\
\text { compositions. }\end{array}$ & 1 & 2 & 3 & 4 & 5 \\
\hline $\begin{array}{l}\text { e. sentence structure errors in the } \\
\text { students' compositions. }\end{array}$ & 1 & 2 & 3 & 4 & 5 \\
\hline
\end{tabular}




\section{Part II.}

Directions: Please answer the following questions. There are no right or wrong answers. I am interested in your opinions.

3. If you want to require students to revise their compositions, when do you provide corrective feedback on grammatical errors? (Please circle only $\underline{\mathrm{ONE}}$ answer.)

a. On the first draft

b. On the second draft

c. On the final draft

d. On every draft

e. On other drafts (Please specify.)

4. If you want to provide corrective feedback on the students' compositions, to what extent do you provide feedback on grammatical errors? (Please circle only $\underline{\mathrm{ONE}}$ answer.)

a. I address all grammatical errors that students make.

b. I address only a few significant grammatical errors.

c. I do not provide any corrective feedback on grammatical errors.

5. In the space provided, please explain your reason(s) for this choice.

6. How do you provide corrective feedback on grammatical errors in the students' compositions? (You can circle more than one answer.)

a. I underlie/circle what is incorrect and write the correct word or structure, e.g., has ate ${ }^{\text {eaten }}$.

b. I show where the error is by underling/circling it, e.g., has ate.

c. I show where the error is and identify the error type by a correction code, e.g., has $\underline{\text { ate }}^{\text {V Form }}$.

d. I indicate that there is an error on a specific line by for example putting a cross $(\times)$ in the margin.

\begin{tabular}{|l|l|}
\hline I buy a cookbook for my mother last year. & $\times$ \\
\hline
\end{tabular}

e. I indicate that there is an error on a specific line by putting a correction code in the margin, e.g., by writing ' $\mathrm{V}$ Tense' in the margin, I show that there is a verb tense error on a specific line.

\begin{tabular}{|l|l|}
\hline I buy a cookbook for my mother last year. & V Tense \\
\hline
\end{tabular}

f. Other (Please specify.)

7. In the space provided, please explain your reason(s) for this choice(s).

8. In general, how carefully do you think students look at the teacher's grammar corrections in their compositions? (Please circle only $\underline{\mathrm{ONE}}$ answer.)

a. They read every correction carefully.

b. They look at some corrections more carefully than at others.

c. They mainly pay attention to direct corrections given by the teacher (e.g., has ate ${ }^{\text {eaten }}$ ).

e. They mainly pay attention to corrections showing directly where the errors are (e.g., has ate or has ate ${ }^{\mathrm{VForm}}$ ).

d. They mainly pay attention to corrections showing indirectly where the errors are (e.g., a cross $(\times)$ or a correction code in the margin).

f. Other (Please specify.)

\section{Part III.}

Directions: The following sentence has been corrected in various ways by different teachers. Look over the different possible corrections and rate each one. If you think, it is a very good way to provide corrective feedback on a grammatical error, circle 1. If you think, it is a very bad way to provide corrective feedback on a grammatical error, 
circle 5. If you think it is somewhere in between, circle the number between 1 and 5 that best represents your opinion.

\begin{tabular}{|l|l|l|l|l|l|}
\hline & $\begin{array}{l}\text { Very } \\
\text { good }\end{array}$ & Good & $\begin{array}{l}\text { Neither } \\
\text { good } \\
\text { nor bad }\end{array}$ & Bad & $\begin{array}{l}\text { Very } \\
\text { bad }\end{array}$ \\
\hline $\begin{array}{l}\text { have been } \\
\text { 9. Since I arrived this city, I am very lonely. }\end{array}$ & 1 & 2 & 3 & 4 & 5 \\
\hline $\begin{array}{l}\text { 10. Since I arrived this city, I am very lonely. } \\
\text { V Tense } \\
\text { 11. Since I arrived this city, I am very lonely. }\end{array}$ & 1 & 2 & 3 & 4 & 5 \\
\hline $\begin{array}{l}\text { 12. Since I arrived this city, I am very lonely. X } \\
\text { 13. Since I arrived this city, I am very lonely. V }\end{array}$ & 1 & 2 & 3 & 4 & 5 \\
\hline Tense
\end{tabular}

A description of the grammatical errors that have been used in this questionnaire comes below:

\begin{tabular}{|c|c|c|}
\hline $\begin{array}{l}\text { Grammatical } \\
\text { errors }\end{array}$ & meaning & Examples \\
\hline Verb errors & Errors in verb tense or form & $\begin{array}{l}\text { - I meet her last week. } \\
\text { - We have not complete the project } \\
\text { yet. }\end{array}$ \\
\hline $\begin{array}{l}\text { Noun ending } \\
\text { errors }\end{array}$ & $\begin{array}{l}\text { Noun ending (plural or possessive) } \\
\text { missing or wrong }\end{array}$ & $\begin{array}{l}\text { - These book } \boldsymbol{\emptyset} \text { are mine. } \\
\text { - My father } \boldsymbol{\emptyset} \text { car is new. }\end{array}$ \\
\hline Article errors & $\begin{array}{l}\text { Article (a, an, the) or other } \\
\text { determiner (some, any, a lot of, } \\
\text { much, many...) missing or wrong }\end{array}$ & $\begin{array}{l}\text { - There are much books on the table. } \\
\text { - I live in the Tabriz. }\end{array}$ \\
\hline Wrong word & $\begin{array}{l}\text { All types of lexical errors in word } \\
\text { choice or form, including } \\
\text { preposition and pronoun errors }\end{array}$ & $\begin{array}{l}\text {-My mother learned me how to ride } \\
\text { a bike. } \\
\text { - I was very interested at history. }\end{array}$ \\
\hline \multirow{4}{*}{$\begin{array}{l}\text { Sentence } \\
\text { structure errors }\end{array}$} & $\begin{array}{l}\text { Errors related to sentence/clause } \\
\text { boundaries }\end{array}$ & $\begin{array}{l}\text { - My father took the bus. Because } \\
\text { the bank was not near. }\end{array}$ \\
\hline & Wrong word order & - What you are doing? \\
\hline & $\begin{array}{l}\text { Omitting words or phrases from a } \\
\text { sentence }\end{array}$ & - I know $\boldsymbol{ø}$ he is. He is at the park. \\
\hline & $\begin{array}{l}\text { Insertion of unnecessary words or } \\
\text { phrases }\end{array}$ & $\begin{array}{l}\text { - The woman whom I saw her was } \\
\text { my teacher. }\end{array}$ \\
\hline
\end{tabular}

